\title{
Validasi Modul "PEREKAT" untuk Meningkatkan Kesiapan Hidup Perkawinan pada Pasangan Pranikah
}

\section{Validation of "PEREKAT" Module to Increase Marital Readiness in Premarital Couple}

Valeria Satwika Anindita', Maria Goretti Adiyanti ${ }^{2}$

Fakultas Psikologi, Universitas Gadjah Mada

Published 28 Oktober 2020

\begin{abstract}
Marital readiness can be increased through premarital education program, still the implementation needs to be improved. Therefore, module development is required as a guide to provide premarital education. This study aimed to validate the "PEREKAT" module in increasing marital readiness. The study instrument used was "PEREKAT" module and marital readiness scale. The study was conducted in two stages; 1 ) validating the module contents through expert judgment, which results show that the module has good content validity; 2 ) validating the functional module through a quasi experiment with an integrated control group designs with dependent pretest and posttest samples. The study participants were 8 premarital couples who will get married in the following 2-12 months. Results of the study indicated that "PEREKAT" module has good content and functional validity to increase marital readiness in premarital couples.
\end{abstract}

Keywords: marital readiness; PEREKAT module; premarital couple

Abstrak. Kesiapan hidup perkawinan dapat ditingkatkan melalui program edukasi pranikah, namun penerapannya masih kurang optimal. Oleh sebab itu diperlukan pengembangan modul sebagai panduan program edukasi pranikah. Penelitian ini bertujuan untuk melakukan validasi terhadap modul "PEREKAT" dalam meningkatkan kesiapan hidup perkawinan pada pasangan pranikah. Intrumen dalam penelitian ini adalah modul "PEREKAT" dan skala kesiapan hidup perkawinan yang disusun oleh peneliti. Penelitian dilakukan dalam dua tahap, yaitu 1) Uji validitas isi modul melalui penilaian tiga ahli sebagai rater. Hasil analisis menunjukkan bahwa modul memiliki validitas isi yang baik; 2) Uji validitas fungsional modul melalui eksperimen kuasi dengan rancangan the untreated control group designs with dependent pretest and posttest samples. Partisipan penelitian sebanyak delapan pasangan pranikah yang akan menikah pertama kali pada 2-12 bulan mendatang. Hasil penelitian menunjukkan bahwa modul "PEREKAT" memiliki validitas isi dan fungsional yang baik untuk meningkatkan kesiapan hidup perkawinan pada pasangan pranikah.

Kata kunci: kesiapan hidup perkawinan; modul "PEREKAT"; pasangan pranikah

Korespondensi mengenai artikel ini dapat dilakukan melalui valeria.satwika.a@mail.ugm.ac.id
Hidup perkawinan merupakan masa yang penuh tantangan bagi individu dewasa. Setiap individu tidak hanya dituntut untuk 
membangun relasi intim dengan pasangan, namun juga dihadapkan pada peran-peran baru dan berbagai perubahan situasi selama menjalani hidup perkawinan (Hurlock, 2011; Olson, DeFrain \& Skogrand, 2014). Fase awal perkawinan dikenal sebagai masa penyesuaian, yakni periode waktu yang paling sulit dalam hidup perkawinan (Afiatin, 2018). Pada fase itu terdapat tuntutan akan pemenuhan kebutuhan hidup bersama antara dua individu yang berbeda, sehingga seringkali menimbulkan perselisihan. Penelitian Lavner, Karney dan Bradbury (2014) menunjukkan bahwa perselisihan atau konflik yang terjadi pada masa awal dan sepanjang hidup perkawinan bersifat menetap. Dengan demikian, dapat dikatakan bahwa hidup perkawinan tidak terlepas dari tantangan dan konflik.

Pada praktiknya, tidak semua pasangan mampu bertahan dalam hidup perkawinan. Sebagian pasangan dapat berhasil membangun relasi yang memuaskan, sehingga mereka cenderung merasa bahagia dan memiliki kesejahteraan hidup yang tinggi (Dush, Taylor, \& Kroeger, 2008; Hansen, Moum, \& Shapiro, 2007; Soons \& Liefbroer, 2008). Sementara itu, sebagian pasangan dapat menghadapi perselisihan terus menerus, sehingga tidak tercipta relasi yang harmonis. Apabila seseorang merasa terbelenggu dalam konflik dan mengalami perasaan tertekan berulang kali, maka kepuasan perkawinannya akan menurun hingga memungkinkan terjadinya perceraian (Hirschberger, Srivastava, Marsh, Cowan, \& Cowan, 2009).

Berdasarkan data Badan Pusat Statistik (2017), kasus perceraian di
Indonesia mengalami peningkatan dari tahun ke tahun. Pada tahun 2013 terdapat 14,67\% kasus perceraian, pada tahun 2014 bertambah menjadi 16,3\%, kemudian meningkat menjadi $17,73 \%$ pada tahun 2015. Pengadilan Agama Yogyakarta mencatat sebanyak 5.412 kasus perceraian terjadi pada tahun 2016. Kasus perceraian sepanjang tahun 2015 hingga 2016 banyak terjadi di wilayah Sleman, di mana sebagian besar putusannya berasal dari gugatan pihak istri.

Keputusan untuk mengakhiri ikatan perkawinan seringkali disebabkan oleh perselisihan yang berkepanjangan dan relasi yang tidak harmonis antara suamiistri. Selain itu, beberapa kondisi yang melatarbelakangi perceraian di antaranya pengabaian nafkah keluarga, penumpukan konflik, perselingkuhan, dan kekerasan dalam rumah tangga (Amato \& Previti, 2003; Birditt, Wan, Orbuch, \& Antonucci, 2017; Chang, 2004; Kustini \& Rosidah, 2016). Meskipun perceraian telah banyak terjadi, namun hal itu tidak menghilangkan keinginan seseorang untuk menikah, melainkan meningkatkan harapan untuk mencapai kebahagiaan dalam perkawinan (Gardner, 2015).

DeGenova dan Rice (2005) mengemukakan bahwa keberhasilan maupun potensi konflik dalam hidup perkawinan sudah dapat diprediksi sejak masa persiapan pernikahan. Hal ini terkait dengan kesiapan pasangan pranikah dalam hidup perkawinan, yakni kesediaan untuk menjalankan peran-peran perkawinan dengan upaya pemenuhan kebutuhan pasangan agar dapat meningkatkan kualitas hubungan (Badger, 2005; Holman \& Li, 1997). Semakin tinggi kesiapan hidup 
perkawinan yang dimiliki, maka semakin besar peluang mereka untuk mencapai perkawinan yang berhasil (Holman, Larson, \& Harmer, 1994; Larson, Newell, Holman \& Feinauer, 2007). Dengan kata lain, kesiapan hidup perkawinan memiliki peran positif terhadap keberhasilan perkawinan dan diharapkan dapat turut mengurangi angka perceraian.

Fenomena yang sering terjadi dalam masa persiapan pernikahan yakni pasangan lebih berfokus pada keberhasilan acara pernikahan, sehingga mengabaikan potensi konflik dalam hidup perkawinan. Berdasarkan analisis kebutuhan melalui wawancara dan observasi, ditemukan bahwa sebagian calon pengantin kurang mampu menerima dan memahami pasangan, mendukung pengembangan diri pasangan, bersikap terbuka, serta menyelesaikan konflik dengan pasangan. Hal tersebut menunjukkan kurangnya kesiapan calon pengantin untuk menjalani hidup perkawinan.

Kesiapan hidup perkawinan terdiri dari empat aspek, yaitu 1) love sebagai kemampuan untuk mencintai pasangan, 2) respect sebagai kemampuan untuk memahami dan menghargai pasangan, 3) communication sebagai kemampuan untuk menyampaikan pendapat secara terbuka dan menyelesaikan masalah secara konstruktif, serta 4) personality fulfillment sebagai kemampuan untuk mendukung pengembangan diri pasangan (Stinnett, dalam Badger, 2005). Tinggi-rendahnya kesiapan hidup perkawinan dapat dipengaruhi oleh latar belakang individu; termasuk relasi dengan keluarga asal, proses interaksi dengan pasangan, kepribadian dan sikap individu, demografi sosial, persetujuan dari orang terdekat, serta pengalaman mengikuti program edukasi pranikah (Badger, 2005; Holman \& Li, 1997; Larson \& LaMont, 2005; McGeorge \& Carlson, 2006). Carroll dan Doherty (2003) mengemukakan bahwa edukasi pranikah merupakan upaya intervensi preventif terhadap proses interaksi pasangan yang terbukti mampu meningkatkan kesiapan hidup perkawinan.

Upaya intervensi preventif terhadap pasangan pranikah telah menjadi perhatian pemerintah akibat tingginya angka perceraian. Kantor Urusan Agama bekerja sama dengan Badan Penasihatan Pembinaan dan Pelestarian Perkawinan dalam memberikan kursus bagi calon pengantin yang berisi materi mengenai pembinaan keluarga sakinah, UndangUndang dan hukum pernikahan, serta kesehatan reproduksi. Kursus yang serupa juga dilaksanakan oleh gereja Kristen dan Katolik. Meski demikian, tidak ada pembahasan materi mengenai hal-hal yang perlu disiapkan secara psikologis untuk menjalani hidup perkawinan. Oleh sebab itu, diperlukan pengembangan program edukasi pranikah.

Penyebab perceraian yang banyak terjadi di Pengadilan Agama Sleman, antara lain tidak adanya penerimaan terhadap sifat dan kekurangan pasangan, tidak adanya penyelesaian masalah secara konstruktif, serta pengabaian terhadap harapan pasangan dalam hidup perkawinan. Seorang hakim di Pengadilan Agama Sleman menjelaskan bahwa sebagian besar konflik dalam perkawinan berakar dari kurangnya sikap saling memahami dan menghargai antar pasangan. Hal ini mendorong peneliti 
untuk merancang program edukasi pranikah yang tidak hanya memfasilitasi pengungkapan diri dan mengembangkan sikap saling memahami, namun juga membekali keterampilan komunikasi dengan pasangan untuk menunjang penyelesaian masalah secara konstruktif.

Penelitian mengenai pentingnya edukasi pranikah terhadap kesiapan hidup perkawinan sudah cukup berkembang di Indonesia. Program Pengenalan Diri dan Pasangan (Novena, 2011) serta Program Tali Hati (Kurniawati, 2011) menjadi acuan peneliti dalam menentukan materi dan kegiatan pada modul "PEREKAT", yang merupakan akronim dari Perkawinan Terencana dan Kuat. Modul ini menggunakan prinsip experential learning menurut ulasan Supratiknya (2011) dan diharapkan dapat menjadi bekal bagi pasangan pranikah untuk mengantisipasi potensi konflik dalam hidup perkawinan. Perbedaan utama dari program yang serupa terletak pada durasi program yang lebih panjang yakni selama tiga pertemuan dan adanya pemberian tugas rumah. Menurut Azwar (2018), untuk mengetahui efektivitas modul yang dapat dipertanggungjawabkan secara ilmiah, maka diperlukan uji kelayakan (validasi) modul. Oleh sebab itu, penelitian ini bertujuan untuk melakukan validasi terhadap modul "PEREKAT" dalam meningkatkan kesiapan hidup perkawinan pada pasangan pranikah.

\section{Metode}

Penelitian ini dilaksanakan dalam dua tahap, yaitu pengujian validitas isi modul dan pengujian validitas fungsional modul.
Kedua tahapan tersebut sesuai dengan proses validasi modul yang dijelaskan oleh Azwar (2018) dan digunakan dalam penelitian yang bertujuan untuk memperoleh validasi modul pelatihan (Chedgy et al., 2017). Pada tahap pertama, pengujian validitas isi modul dilakukan melalui expert judgment, yakni pemberian rating oleh tiga ahli dalam bidang psikologi keluarga dan perkawinan. Ketiga ahli memberi penilaian (rating) terhadap kesesuaian isi modul dengan tujuan dan indikator kegiatan, alokasi waktu, serta penggunaan bahasa yang mudah dipahami.

Tahap kedua dalam proses validasi modul adalah pengujian validitas fungsional. Menurut Azwar (2018), validitas fungsional modul dapat dibuktikan melalui penelitian dengan desain eksperimen, sehingga dapat diketahui signifikansi perubahan skor variabel tergantung yang terjadi setelah perlakuan diberikan. Tahap pengujian ini dilakukan dengan metode eksperimenkuasi. Desain penelitian yang digunakan adalah the untreated control group design with dependent pretest and posttest samples (Shadish, Cook, \& Campbell, 2002). Desain eksperimen ini melibatkan dua kelompok sampel partisipan, yaitu kelompok eksperimen yang diberi perlakuan berupa program "PEREKAT" dan kelompok kontrol yang tidak diberi perlakuan. Desain penelitian tertera pada Gambar 1.

\section{Partisipan}

Partisipan penelitian terdiri dari delapan pasangan pranikah dengan rentang usia 2229 tahun. Pemilihan partisipan dilakukan menggunakan teknik purposive sampling, dengan penetapan kriteria yang didasarkan 


\begin{tabular}{|cccccc|}
\hline KE: & NR & $\mathrm{O}_{1}$ & X & $\mathrm{O}_{2}$ & $\mathrm{O}_{3}$ \\
$\mathrm{KK}:$ & $\mathrm{NR}$ & $\mathrm{O}_{1}$ & & $\mathrm{O}_{2}$ & \\
\hline
\end{tabular}

Gambar 1. Desain Penelitian

Keterangan:

KE : kelompok eksperimen

KK : kelompok kontrol

NR : non-random

$\mathrm{O}_{1} \quad$ : pretest kesiapan hidup perkawinan

$\mathrm{X}$ : perlakuan atau intervensi dengan modul "PEREKAT"

$\mathrm{O}_{2} \quad$ : posttest kesiapan hidup perkawinan

$\mathrm{O}_{3}$ : follow-up kesiapan hidup perkawinan

pada beberapa pertimbangan. Pertama, berdasarkan komponen program edukasi pranikah yang efektif yakni diberikan 12 bulan sebelum pasangan menikah atau setidaknya enam hingga delapan bulan minggu sebelum pernikahan (Olson et al., 2014). Kedua, berdasarkan kebutuhan untuk menjawab pertanyaan penelitian, sehingga dimasukkan kriteria skor kesiapan hidup perkawinan yang berada pada kategori sedang. Ketiga, berdasarkan kebutuhan pelaksanaan Program "PEREKAT" di antaranya; belum pernah mengikuti edukasi pranikah bersama pasangan, latar belakang pendidikan minimal SMA/sederajat, serta bersedia mengikuti prosedur penelitian dengan menandatangani informed consent. Data demografis partisipan penelitian tertera pada Tabel 1.

\section{Prosedur}

Pada tahap persiapan penelitian, peneliti terlebih dahulu menyusun modul "PEREKAT" menggunakan konstruksi modul dari Russell (1974). Langkahlangkah yang dilakukan antara lain, 1)
Menentukan tujuan modul, yakni meningkatkan kesiapan hidup perkawinan; 2) Menyusun alat ukur, yakni skala kesiapan hidup perkawinan; 3) Menyusun blueprint modul "PEREKAT". Setelah itu, dua langkah terakhir adalah melakukan uji kelayakan (validasi) modul secara isi dan empirik, kemudian mengevaluasi hasil uji kelayakan dan menyempurnakan modul agar dapat diimplementasikan.

Peneliti menentukan beberapa kriteria pada fasilitator, co-fasilitator dan observer penelitian untuk menunjang teknis pelaksanaan program "PEREKAT". Satu orang fasilitator ditentukan berdasarkan kualifikasi berikut: psikolog yang memiliki Surat Ijin Praktik Psikologi (SIPP), sudah menikah, dan memiliki pengalaman menangani kasus dalam ranah perkawinan dan keluarga. Kualifikasi cofasilitator yang dibutuhkan yaitu mahasiswa Magister Psikologi Profesi bidang klinis yang telah menyelesaikan Praktik Kerja Profesi Psikologi, sehingga mampu memfasilitasi proses diskusi pasangan. Jumlah co-fasilitator disesuaikan dengan jumlah pasangan (satu co- 
Tabel 1.

Data Demografis Partisipan Penelitian

\begin{tabular}{cccccc}
\hline Kelompok & $\begin{array}{c}\text { Inisial } \\
\text { Nama }\end{array}$ & $\begin{array}{c}\text { Jenis } \\
\text { Kelamin }\end{array}$ & $\begin{array}{c}\text { Usia } \\
\text { (tahun) }\end{array}$ & $\begin{array}{c}\text { Pendidikan } \\
\text { terakhir }\end{array}$ & $\begin{array}{c}\text { Rencana } \\
\text { pernikahan }\end{array}$ \\
\hline \multirow{5}{*}{ Eksperimen } & YM & P & 26 & S1 & $2-5$ bulan \\
& MR & L & 26 & S1 & mendatang \\
\cline { 2 - 6 } & AS & P & 25 & S1 & 12 bulan \\
& FS & L & 26 & S1 & mendatang \\
\cline { 2 - 6 } & FH & P & 22 & SMA & $6-11$ bulan \\
& AL & L & 22 & SMA & mendatang \\
\cline { 2 - 6 } & AM & P & 23 & S1 & 12 bulan \\
& NR & L & 27 & S1 & mendatang \\
\hline \multirow{5}{*}{ Kontrol } & AR & P & 27 & S1 & 12 bulan \\
& YK & L & 29 & SMA & mendatang \\
\cline { 2 - 6 } & PP & P & 23 & S1 & $6-11$ bulan \\
& FA & L & 23 & S1 & mendatang \\
\cline { 2 - 6 } & KK & P & 23 & S1 & 12 bulan \\
& AB & L & 24 & SMA & mendatang \\
\cline { 2 - 6 } & YR & P & 25 & S1 & $2-5$ bulan \\
& DF & L & 27 & S1 & mendatang \\
\hline
\end{tabular}

fasilitator akan mendampingi satu pasangan). Sementara dua orang observer ditentukan dengan kriteria lulusan S1 Psikologi yang sudah mendapatkan mata kuliah observasi serta memahami proses asesmen psikologi.

Proses perekrutan partisipan dilakukan secara terbuka (open recruitment) melalui penyebaran informasi di media sosial WhatsApp, Line dan Instagram. Partisipan terpilih yang memenuhi kriteria dibagi ke dalam kelompok eksperimen dan kontrol berdasarkan kesesuaian waktu untuk mengikuti rangkaian program "PEREKAT". Masing-masing kelompok terdiri dari delapan orang calon pengantin (4 laki-laki dan 4 perempuan).

Tahap pelaksanaan penelitian diawali dengan proses validasi isi modul yang berlangsung selama kurang lebih dua minggu (16-30 April 2019). Setelah proses validasi isi selesai, peneliti melakukan simulasi pelaksanaan program "PEREKAT" bersama fasilitator dan co-fasilitator. Selanjutnya proses validasi fungsional modul dilakukan dengan pengukuran kesiapan hidup perkawinan pada partisipan dan pelaksanaan program "PEREKAT" pada tanggal 4, 5, dan 11 Mei 2019 di Fakultas Psikologi UGM. Setiap pertemuan berlangsung selama \pm 210 menit.

\section{Instrumen}

Instrumen yang digunakan dalam penelitian ini adalah modul "PEREKAT" dan skala kesiapan hidup perkawinan. Blueprint modul "PEREKAT" tertera pada Tabel 2. Skala kesiapan hidup perkawinan disusun oleh peneliti berdasarkan empat aspek kesiapan hidup perkawinan yang dikemukakan oleh Stinnet (dalam Badger, 2005). Skala sikap ini berisi 20 aitem yang terdiri dari aitem favorabel dan unfavorabel. Nilai V yang diperoleh bergerak dari 0,833 hingga 1,00, artinya skala ini memiliki koefisien validitas isi yang tinggi (Azwar, 
Tabel 2.

Blueprint Modul "PEREKAT"

\begin{tabular}{|c|c|c|c|}
\hline Sesi & Tujuan & Aktivitas & Durasi \\
\hline \multicolumn{4}{|c|}{ Pertemuan ke-1 } \\
\hline $\begin{array}{l}\text { Mengenali dan } \\
\text { Menerima Karakteristik } \\
\text { Pasangan } \\
\text { (aspek love) }\end{array}$ & $\begin{array}{l}\text { Partisipan merasa aman dengan } \\
\text { adanya keterbukaan dengan } \\
\text { pasangan, sehingga mampu } \\
\text { menerima sifat-sifat yang dimiliki } \\
\text { pasangan. }\end{array}$ & $\begin{array}{l}\text { Diskusi kasus } \\
\text { (penayangan video), } \\
\text { pengerjaan tugas, dan } \\
\text { sharing. }\end{array}$ & 90 menit \\
\hline $\begin{array}{lr}\text { Memahami } & \text { dan } \\
\text { Menghargai } & \\
\text { Karakteristik } & \text { Keluarga } \\
\text { Asal } & \\
\text { (aspek respect) } & \\
\end{array}$ & $\begin{array}{l}\text { Partisipan memahami adanya } \\
\text { pengaruh dari keluarga asal, } \\
\text { sehingga mampu menghargai sikap } \\
\text { dan sifat yang dimiliki pasangan. }\end{array}$ & $\begin{array}{l}\text { Ceramah interaktif, } \\
\text { pengerjaan tugas, } \\
\text { diskusi dan sharing. }\end{array}$ & 75 menit \\
\hline \multicolumn{4}{|c|}{ Pertemuan ke-2 } \\
\hline $\begin{array}{l}\text { Pola Interaksi Pasangan } \\
\text { (aspek respect) }\end{array}$ & $\begin{array}{l}\text { Partisipan memahami pentingnya } \\
\text { menjalin interaksi positif dengan } \\
\text { pasangan, yang ditunjukkan dengan } \\
\text { adanya kesepakatan, persetujuan, } \\
\text { dan upaya untuk mendengarkan } \\
\text { secara aktif. }\end{array}$ & $\begin{array}{l}\text { Permainan, } \\
\text { pengerjaan tugas, } \\
\text { ceramah interaktif, } \\
\text { diskusi dan sharing. }\end{array}$ & 75 menit \\
\hline $\begin{array}{l}\text { Komunikasi Pasangan } \\
\text { (aspek communication) }\end{array}$ & $\begin{array}{l}\text { - Partisipan mampu menyampaikan } \\
\text { hal yang diinginkannya secara } \\
\text { langsung tanpa menyakiti ataupun } \\
\text { mengkritik pasangan, serta mampu } \\
\text { mendengarkan perkataan pasangan } \\
\text { secara akurat dan menyampaikan } \\
\text { kembali apa yang telah } \\
\text { didengarnya. } \\
\text { - Partisipan memahami dan mampu } \\
\text { menerapkan upaya penyelesaian } \\
\text { masalah secara konstruktif. }\end{array}$ & $\begin{array}{l}\text { Ceramah interaktif, } \\
\text { bermain peran (role } \\
\text { play), pengerjaan } \\
\text { tugas, diskusi dan } \\
\text { sharing. }\end{array}$ & $\begin{array}{c}100 \\
\text { menit }\end{array}$ \\
\hline \multicolumn{4}{|c|}{ Pertemuan ke-3 } \\
\hline $\begin{array}{l}\text { Harapan dalam Hidup } \\
\text { Perkawinan } \\
\text { (aspek personality } \\
\text { fulfillment) }\end{array}$ & $\begin{array}{l}\text { Partisipan memberi afirmasi atau } \\
\text { dukungan terhadap upaya } \\
\text { pengembangan diri pasangannya. }\end{array}$ & $\begin{array}{l}\text { Pengerjaan tugas, } \\
\text { diskusi dan sharing. }\end{array}$ & 75 menit \\
\hline
\end{tabular}

2014). Setelah dilakukan uji coba empirik, skala ini memiliki nilai reliabilitas 0,839 .

\section{Analisis}

Pada tahap pengujian validitas isi, data dianalisis dengan rumus Aiken's V untuk menghasilkan nilai content-validity coefficient. Selanjutnya pada tahap pengujian validitas fungsional, analisis statistik yang digunakan adalah uji non- parametrik Mann-Whitney U (Azwar, 2018). Uji non-parametrik digunakan karena jumlah sampel yang terbilang sedikit. Analisis tambahan dilakukan dengan uji non-parametrik sign-rank Wilcoxon untuk mengetahui sejauh mana pengaruh intervensi dapat bertahan pada kelompok eksperimen (Azwar, 2016). Selain itu, peneliti juga menganalisis perubahan aspek-aspek kesiapan hidup perkawinan 
Tabel 3.

Hasil Pengukuran Kesiapan Hidup Perkawinan pada Kelompok Eksperimen dan Kelompok Kontrol

\begin{tabular}{cccccccc}
\hline Kelompok & Inisial & Pretest & Kategori & Posttest & Kategori & $\begin{array}{c}\text { Gain } \\
\text { score }\end{array}$ & $\begin{array}{c}\text { Follow } \\
\text { up }\end{array}$ \\
\hline \multirow{6}{*}{ Eksperimen } & YM & 66 & Sedang & 70 & Sedang & 4 & 70 \\
& MR & 71 & Sedang & 76 & Tinggi & 5 & 77 \\
& AS & 67 & Sedang & 75 & Tinggi & 8 & 77 \\
& FS & 69 & Sedang & 72 & Sedang & 3 & 73 \\
& FH & 62 & Sedang & 67 & Sedang & 5 & 67 \\
& AL & 68 & Sedang & 71 & Sedang & 3 & 73 \\
& AM & 71 & Sedang & 76 & Tinggi & 5 & 78 \\
\hline Rata-rata & NR & 72 & Sedang & 76 & Tinggi & 4 & 77 \\
\hline \multirow{5}{*}{ Kontrol } & AR & 68,3 & & 73 & & 4,6 & 74 \\
& YK & 71 & Sedang & 68 & Sedang & 4 & - \\
& PP & 57 & Sedang & 70 & Sedang & -1 & - \\
& FA & 72 & Sedang & 60 & Sedang & 3 & - \\
& KK & 63 & Sedang & 62 & Sedang & -3 & - \\
& AB & 63 & Sedang & 67 & Sedang & -1 & - \\
& YR & 71 & Sedang & 67 & Sedang & 4 & - \\
& DF & 72 & Sedang & 66 & Sedang & -6 & - \\
\hline Rata-rata & & 66,6 & & 66,1 & & $-0,5$ & \\
\hline
\end{tabular}

dengan membandingkan nilai rata-rata setiap aspek saat pretest, posttest dan follow up pada kelompok eksperimen.

\section{Hasil}

Analisis dengan rumus Aiken's V terhadap penilaian ketiga rater menunjukkan rentang angka $\mathrm{V}$ antara $0,75-1,00$. Berdasarkan pendapat Azwar (2018), koefisien V yang lebih tinggi dari 0,50 dianggap sebagai indikasi adanya validitas isi yang baik. Angka rata-rata dari seluruh koefisien $\mathrm{V}$ sub-bagian modul yang diperoleh sebesar 0,943, sehingga modul "PEREKAT" memiliki validitas isi yang baik dan layak digunakan. Berdasarkan koefisien $\mathrm{V}$ yang diperoleh, dapat dikatakan bahwa 94,3\% isi kegiatan dalam modul telah sesuai dengan tujuan yang ingin dicapai.
Setelah pelaksanaan intervensi dengan program "PEREKAT", didapatkan perubahan skor dari hasil pretest dan posttest pada kelompok eksperimen dan kelompok kontrol. Rincian skor kesiapan hidup perkawinan pada setiap pengukuran tertera pada tabel 3.

Analisis dengan uji Mann-Whitney $U$ menghasilkan nilai $Z=-2,663$ dengan $p$ sebesar 0,008 $(p<0,05)$. Hasil tersebut menunjukkan adanya perbedaan yang signifikan antara gain score kelompok eksperimen dengan gain score kelompok kontrol. Berdasarkan data pretest dan posttest, partisipan di kelompok eksperimen mengalami peningkatan skor kesiapan hidup perkawinan yang lebih tinggi dibandingkan partisipan di kelompok kontrol. Pada kelompok eksperimen, uji sign-rank Wilcoxon menghasilkan nilai $Z$ = - 
1.857 dengan $p=0,063(p>0,05)$. Hal ini berarti tidak ada perbedaan yang signifikan antara skor posttest dan follow up. Selain itu, hasil perbandingan skor rata-rata keempat aspek kesiapan hidup perkawinan pada kelompok eksperimen menunjukkan bahwa aspek respect mengalami peningkatan paling tinggi dan diikuti dengan aspek communication.

\section{Diskusi}

Modul "PEREKAT" (Perkawinan Terencana dan Kuat) merupakan panduan yang digunakan untuk melaksanakan program edukasi pranikah. Modul ini dapat diterapkan dalam program edukasi bagi pasangan pranikah, khususnya yang akan menikah untuk pertama kalinya pada 2-12 bulan mendatang. Modul "PEREKAT" dapat menjawab kebutuhan akan pemahaman mengenai tantangan dan potensi konflik dalam hidup perkawinan, serta pentingnya memperkuat relasi pasangan pranikah melalui pola komunikasi yang sehat. Setelah mengikuti rangkaian kegiatan dalam modul "PEREKAT", pasangan pranikah menjadi lebih siap untuk menjalani hidup perkawinan.

Modul "PEREKAT" layak digunakan dalam program edukasi pranikah karena telah tervalidasi. Proses validasi modul dilakukan dalam dua tahap, yaitu pengujian secara isi dan fungsional. Hal ini sejalan dengan tahapan validasi modul yang disarankan oleh Azwar (2018). Peneliti telah meminta masukan dari para ahli yang kompeten di bidang terkait, kemudian melakukan uji coba pada subjek yang menjadi target pemberian modul (Ayriza, 2008; Russell, 1974).

Penelitian ini berhasil membuktikan bahwa modul program "PEREKAT" dapat meningkatkan kesiapan hidup perkawinan pada pasangan pranikah. Hal ini didukung oleh proses penyusunan modul yang dilakukan sesuai konstruksi modul menurut Russell (1974). Selain itu, materi dan aktivitas dalam modul "PEREKAT" juga didasarkan pada bukti empiris penelitian-penelitian terdahulu. Beberapa hasil penelitian mengenai program edukasi pranikah yang dijadikan acuan, antara lain Empowering Couples (Olson \& Olson, 2000), Marital Assessment and Preparation (McGeorge \& Carlson, 2006), Program Pengenalan Diri dan Pasangan (Novena, 2011) dan Program Tali Hati (Kurniawati, 2011).

Hasil penelitian ini telah mendukung hasil penelitian sebelumnya yang menyatakan bahwa program edukasi pranikah dapat menghasilkan kesiapan pasangan calon pengantin untuk menjalani hidup perkawinan (Carroll \& Doherty, 2003; Futris, Barton, Aholou, \& Seponski, 2011; McGeorge \& Carlson, 2006). Pasangan calon pengantin yang mengikuti program persiapan pernikahan menunjukkan peningkatan yang signifikan terhadap kesiapan untuk menjalani hidup perkawinan (Kurniawati, 2011; Novena, 2011). Hasil pengukuran tindak lanjut juga menunjukkan bahwa pengaruh program "PEREKAT" terhadap peningkatan kesiapan hidup perkawinan cenderung stabil hingga 2 minggu setelah berakhirnya program.

Hasil analisis skor rata-rata tiap aspek dalam modul "PEREKAT" 
menunjukkan bahwa aspek respect mengalami peningkatan paling tinggi dibandingkan aspek lainnya. Hal ini dapat dikarenakan materi dan kegiatan yang menyasar pada aspek tersebut memiliki proporsi yang lebih besar. Berdasarkan hasil evaluasi program, partisipan menyatakan bahwa program "PEREKAT" dapat membantu mereka untuk lebih memahami pasangan. Selain itu, peningkatan respect dalam kesiapan hidup perkawinan juga sejalan dengan pernyataan hakim di Pengadilan Agama Sleman mengenai pentingnya sikap memahami dan menghargai pasangan untuk mencegah perceraian.

Imanita (2018) mengungkapkan bahwa kesiapan hidup perkawinan perlu dimiliki oleh individu dewasa yang sedang mempersiapkan pernikahan. Kesiapan itu dapat ditunjukkan dengan kemampuan untuk memenuhi kebutuhan dalam relasi perkawinan, sehingga potensi konflik dapat diantisipasi. Modul "PEREKAT" berisi materi dan kegiatan yang mampu meningkatkan kesiapan untuk menjalani hidup perkawinan. Modul ini disusun berdasarkan aspek-aspek kesiapan hidup perkawinan yang dikemukakan oleh Stinnett (dalam Badger, 2005), yaitu love, respect, communication, dan personality fulfillment.

Pengetahuan dan pengalaman yang dimiliki fasilitator menjadi salah satu karakteristik penting dalam membangun kepercayaan partisipan, sehingga dapat menunjang keberhasilan program pelatihan (Cranley, Cummings, Profetto-McGrath, Tot \& Estrabrooks, 2017). Fasilitator dalam penelitian ini berprofesi sebagai psikolog bidang klinis yang berfokus pada penanganan individu dewasa. Fasilitator memiliki kualifikasi yang memadai, yaitu sudah menikah, berpengalaman memberikan psikoedukasi kepada pasangan calon pengantin, serta menangani perselisihan antara suami-istri dengan konseling perkawinan. Oleh karena itu, fasilitator dapat memberikan gambaran mengenai hal-hal yang berpotensi menimbulkan konflik dalam hidup perkawinan, serta memaparkan pentingnya kesiapan hidup perkawinan dalam hal interaksi pasangan.

Pelaksanaan program "PEREKAT" tidak hanya difasilitasi oleh seorang fasilitator, namun juga melibatkan beberapa ko-fasilitator. Setiap ko-fasilitator bertugas mendampingi dua partisipan yang berpasangan. Peran co-fasilitator dalam mendampingi proses diskusi pasangan partisipan berpengaruh terhadap keberhasilan program edukasi pranikah (Novena, 2011). Fasilitator dalam penelitian ini menilai bahwa keterlibatan co-fasilitator telah membuat pelaksanaan program menjadi lebih efisien.

Keberhasilan program pelatihan juga didukung oleh kesiapan partisipan yang meliputi sikap dan motivasi positif terhadap program (Afiatin, Sonjaya, \& Pertiwi, 2013). Hal ini sejalan dengan pendapat Carroll \& Doherty, (2003) bahwa kesediaan dan keaktifan partisipan dalam mengikuti program dan mengerjakan tugas menjadi faktor penting dalam keberhasilan program. Partisipan menunjukkan antusiasme yang baik selama program berlangsung. Berdasarkan hasil observasi, partisipan terlihat fokus dan memperhatikan saat fasilitator menyampaikan materi, merespon instruksi 
yang diberikan, terlibat aktif dalam setiap aktivitas, serta memberikan pendapat saat kegiatan diskusi.

Adapun beberapa kelemahan dari penelitian ini terkait dengan keterbatasan yang terjadi dalam proses pengambilan data. Pertama, terdapat ancaman validitas internal berupa testing. Penelitian ini menggunakan pengukuran berulang sebanyak tiga kali dengan alat ukur yang sama, sehingga memungkinkan adanya efek belajar pada partisipan. Meskipun demikian, kondisi ini telah diantisipasi oleh peneliti dengan mengubah tampilan skala serta melakukan pengacakan nomer aitem. Kedua, pengukuran tindak lanjut yang dilakukan dua minggu setelah program berakhir mengindikasikan bahwa efek keberlangsungan program hanya diketahui dalam jangka pendek. Pengukuran tindak lanjut dalam kurun waktu yang relatif lebih panjang dapat menggambarkan perubahan sikap maupun perilaku yang menetap.

Keterbatasan dalam penelitian ini juga terkait jumlah partisipan yang terbilang sedikit. Hal ini berdampak pada metode analisis data yang dilakukan dengan statistika non parametrik, sehingga cenderung memiliki power efficiency yang rendah dibandingkan analisis statistik parametrik (Azwar, 2016). Power efficiency mengindikasikan kemampuan suatu pengujian tes untuk menerima hipotesis nihil yang memang seharusnya diterima. Selain itu, hasil analisis statistika non parametrik juga memiliki kelemahan dalam fungsi generalisasi. Dengan demikian, hasil penelitian ini hanya berlaku pada kelompok tertentu dengan karakteristik partisipan yang serupa.

\section{Kesimpulan}

Penelitian ini menunjukkan bahwa modul "PEREKAT" memiliki validitas secara isi dan fungsional yang layak digunakan sebagai panduan dalam program edukasi pranikah. Modul ini berisi materi dan kegiatan yang cocok diberikan kepada pasangan calon pengantin, khususnya yang akan menikah untuk pertama kali dalam rentang waktu 2-12 bulan mendatang. Berdasarkan hasil analisis data, program "PEREKAT" mampu meningkatkan kesiapan hidup perkawinan pada pasangan pranikah. Partisipan penelitian memperoleh manfaat positif dari program yang telah diikuti. Program "PEREKAT" dapat membantu partisipan untuk mengantisipasi potensi konflik dalam hidup perkawinan melalui pengembangan sikap memahami dan menghargai pasangan. Selain itu, relasi dengan pasangan juga dapat semakin kuat berkat pengembangan keterampilan komunikasi yang sehat.

Saran

Bagi psikolog atau praktisi yang menggeluti bidang konseling perkawinan dan keluarga, modul "PEREKAT" dapat digunakan sebagai panduan program edukasi pranikah. Program ini dapat diberikan dalam bentuk kelompok yang terdiri dari beberapa pasangan maupun hanya sepasang calon pengantin, karena program ini berfokus pada proses interaksi antar pasangan dengan didampingi oleh fasilitator. Bagi peneliti selanjutnya, disarankan untuk melakukan uji coba modul dengan melibatkan jumlah partisipan yang lebih banyak, memberikan 
tes pengetahuan sebagai upaya cek manipulasi dan melakukan pengukuran jangka panjang untuk mengetahui efek keberlangsungan dari program "PEREKAT".

\section{Daftar Pustaka}

Afiatin, T. (2018). Psikologi perkawinan dan keluarga: Penguatan keluarga di era digital berbasis kearifan lokal. Yogyakarta: Kanisius.

Afiatin, T., Sonjaya, J., A., \& Pertiwi, Y. G. (2013). Mudah dan sukses menyelenggarakan pelatihan, melejitkan potensi diri. Yogyakarta: Kanisius.

Amato, P. R., \& Previti, D. (2003). People's reasons for divorcing: Gender, social class, the life course, and adjustment. Journal of Family Issues, 24(5), 602-626. doi:

https://doi.org/10.1177/0192513X03254 $\underline{507}$

Ayriza, Y. (2008). Penyusunan dan validasi modul "social life skill" bagi pendidik anak-anak prasekolah. Jurnal Penelitian dan Evaluasi Pendidikan, 10(2), 213-231.

doi: https://doi.org/10.21831/pep.v12i2.142 $\underline{8}$

Azwar, S. (2014). Metode penelitian. Yogyakarta: Pustaka Pelajar.

Azwar, S. (2016). Aplikasi mudah statistika non-parametrik. Yogyakarta: Pustaka Pelajar.

Azwar, S. (2018). Metode penelitian Psikologi (Edisi kedua). Yogyakarta: Pustaka Pelajar.

Badan Pusat Statistik (2017). Nikah, talak dan cerai, serta rujuk, 2007-2016. Diakses melalui http://www.bps.go.id/dynamictable/2

017/03/03/893/nikah-talak-dan-cerai-

serta-rujuk-2012-2015 (pada 17

Desember 2018)

Badger, S. (2005). Ready or not? Perceptions of marriage readiness among emerging adults (Disertasi tidak dipublikasikan). Brigham Young University, Provo.

Birditt, K. S., Wan, W. H., Orbuch, T. L., \& Antonucci, T. C. (2017). The development of marital tension: Implications for divorce among married couples. Developmental Psychology, 53(10), 1995-2006. doi: https://doi.org/10.1037/dev0000379

Carroll, J. S., \& Doherty, W. J. (2003). Evaluating the effectiveness of premarital prevention programs: A meta-analytic review of outcome research. Family Relations: An Interdisciplinary Journal of Applied Family Studies, 52(2), 105-118. doi: https://doi.org/10.1111/j.17413729.2003.00105.x

Chang, J. (2004). Self-reported reasons for divorce and correlates of psychological well-being among divorced Korean immigrant women. Journal of Divorce \& Remarriage, 40(12), 111-128. doi: https://doi.org/10.1300/J087v40n01 08 Chedgy, F. J. Q., Kandiah, K., Barr, H., DeCaestecker, J., Dwerryhouse, S., Bhandari, P. (2017). Development and validation of a training module on the use of acetic acid for the detection of Barrett's neoplasia. Endoscopy, 49(2), 121-129. doi: http://doi.org/10.1055/s$\underline{0042-120179}$ 
Cranley, L.A., Cummings, G.G., ProfettoMcGrath, J., Toth, F., \& Estrabrooks, C.A. (2017). Facilitation roles and characteristics associated with research use by healthcare professionals: A scoping review. BMJ Open. doi: http://dx.doi.org/10.1136/bmjopen2016-014384

DeGenova, M. K., \& Rice, F. P. (2005). Intimate relationships, marriages, and families. New York: McGraw Hill.

Dush, C. M. K, Taylor, M. G., \& Kroeger, R. A. (2008). Marital happiness and psychological well-being acros the life course. Family Relations, 57(2), 211226.

doi:

http://dx.doi.org/10.1111/j.17413729.2008.00495.x

Futris, T. G., Barton, A. W., Aholou, T. M., \& Seponski, D. M. (2011). The impact of PREPARE on engaged couples: Variations by delivery format. Journal of Couple E Relationship Therapy, 10(1), 69-86.

doi: https://doi.org/10.1080/15332691.2011. $\underline{539175}$

Gardner, R. A. (2015). Psychological aspects of divorce. In International Psychotherapy Institute. Diakses melalui

https://www.freepsychotherapybooks .org/ebook/psychological-aspects-ofdivorce/

Hansen, T., Moum, T., \& Shapiro, A. (2007). Relational and individual well-being among cohabitors and married individuals in midlife: Recent trends from Norway. Journal of Family Issues. 28(7), 910-933.

doi:
https://doi.org/10.1177/0192513X07299 $\underline{610}$

Hirschberger, G., Srivastava, S., Marsh, P., Cowan, P., \& Cowan, P.A. (2009). Attachment, marital satisfaction, and divorce during the first fifteen years of parenthood. Personal Relationship, 16(3), 401-420. doi: https://doi.org/10.1111/j.14756811.2009.01230.x

Holman, T. B., Larson, J. H., \& Harmer, S. L. (1994). The development and predictive validity of a new premarital assessment instrument: The preparation for marriage questionnaire. Family Relations, 43(1), 46-52.

doi: http://doi.org/10.2307/585141

Holman, T. B., \& Li, B. D. (1997). Premarital factors influencing perceived readiness for marriage. Journal of Family Issues, 18(2), 124-144. doi: https://doi.org/10.1177/0192513970180 $\underline{02002}$

Hurlock, E. B. (2011). Psikologi perkembangan: Suatu pendekatan sepanjang rentang kehidupan. Jakarta: Erlangga.

Imanita, M. R. (2018). Hubungan antara komunikasi pranikah dan dukungan sosial dengan kesiapan menikah (Tesis tidak dipublikasikan). Direktorat Program Pascasarjana, Universitas Muhammadiyah Malang, Malang.

Kurniawati, Y. (2011). Program Tali Hati untuk meningkatkan kesiapan pernikahan dalam hal komunikasi pada pasangan pranikah. (Tesis tidak dipublikasikan). Fakultas Psikologi, Universitas Gadjah Mada, Yogyakarta. 
Kustini, \& Rosidah, I. (2016). Ketika perempuan bersikap: Tren cerai gugat masyarakat Muslim. Jakarta: Puslitbang Kehidupan Keagamaan, Badan Litbang dan Diklat, Kementerian Agama.

Larson, J. H., \& LaMont, C. (2005). The relationship of childhood sexual abuse to the marital attitudes and readiness for marriage of single young adult women. Journal of Family Issues, 26(4), 415-430. doi: https://doi.org/10.1177/0192513X04270 $\underline{474}$

Larson, J. H., Newell, K. E., Holman, T. B., \& Feinauer, I. D. (2007). The role of family environment in the dating relationships and readiness for marriage of young adult male survivors of non-familial childhood sexual abuse. The American Journal of Family Therapy, 35(3), 173-186. doi: https://doi.org/10.1080/0192618060096 $\underline{8423}$

Lavner, J. A., Karney, B. R., \& Bradbury, T. N. (2014). Relationship problems over the early years of marriage: Stability or change?. Journal of Family Psychology, 28(6), 979-985. doi: https://doi.org/10.1037/a0037752

McGeorge, C. R. \& Carlson, T. S. (2006). Premarital education: An assessment of program efficacy. Contemporary Family Therapy, 28(1), 165-190. doi: https://doi.org/10.1007/s10591-0069701-8

Novena, P. T. (2011). Program Pengenalan Diri dan Pasangan untuk meningkatkan kesiapan pernikahan pada pasangan pranikah. (Tesis tidak dipublikasikan). Fakultas Psikologi, Universitas Gadjah Mada, Yogyakarta.

Olson, D., DeFrain, J., \& Skogrand, L. (2014). Marriages and families: Intimacy, diversity and strengths (Edisi kedelapan). New York: McGraw-Hill.

Olson, D. H., \& Olson, A. K. (2000). Empowering couples: Building on your strengths. Minnesota: Life Innovations, Inc.

Pengadilan Agama Sleman Kelas 1A. (2017, 12 December). Artikel. Dipetik 11 April 2019, dari website: https://www.pa-slemankab.go.id/

Russell, J. D. (1974). Modular instruction: A guide to the design, selection, utilization and evaluation of modular materials. Minneapolis: Burgess Publishing Company.

Shadish, W. R., Cook, T. D., Campbell, D. T. (2002). Experimental and designs for generalized causal inference. Experimental and quasi-experimental design for causal inference. Boston: Houghton Mifflin Company.

Soons, J. P., \& Liefbroer, A. C. (2008). Together is better? Effects of relationship status and resources on young adults' well-being. Journal of Social and Personal Relationships, 25(4), 603-624.

doi: https://doi.org/10.1177/0265407508093 $\underline{789}$

Supratiknya, A. (2011). Merancang program dan modul psikoedukasi (Edisi revisi). Yogyakarta: Universitas Sanata Dharma 